\section{Synthesis of Exiguamine A}

Key words

\section{exiguamines}

Henry reaction

Hemetsberger indole cyclization

oxa-6 $\pi$ electrocyclization<smiles>CCCOc1cc(Br)ccc1C=O</smiles>

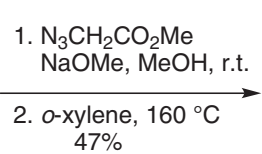<smiles>CC(=O)c1cc2c(OCc3ccccc3)cc(Br)cc2[nH]1</smiles>

1. $3 \mathrm{M} \mathrm{NaOH}, \Delta$

2. $\mathrm{CuSO}_{4}, \mathrm{Na}_{2} \mathrm{CO}_{3}$, $\mathrm{H}_{2} \mathrm{O}, 75^{\circ} \mathrm{C}$

\section{3. quinoline, $215^{\circ} \mathrm{C}$} $72 \%$<smiles>O=C(O)c1cc(Br)cc2[nH]ccc12</smiles>

4 steps $\mid 68 \%$

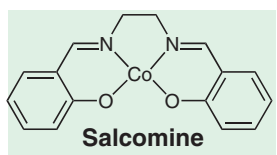

1. Pd black, $\mathrm{HCO}_{2} \mathrm{NH}_{4}$ $\mathrm{EtOH}, 40{ }^{\circ} \mathrm{C}$

2. salcomine, $\mathrm{O}_{2}$ $\mathrm{MeCN}$, r.t.

3. $1 \%$ aq $\mathrm{HCO}_{2} \mathrm{H}$

$\mathrm{Me}_{2} \mathrm{~N}^{-}$

$72 \%$

1. H, LHMDS, THF, -78 to $-40^{\circ} \mathrm{C}$

$26 \%$ 2. $\mathrm{BBr}_{3}, \mathrm{CH}_{2} \mathrm{Cl}_{2},-78^{\circ} \mathrm{C}$ to r.t. 3. $\mathrm{HCO}_{2} \mathrm{H}-\mathrm{MeOH}$, r.t.<smiles>CNCCc1ccc(O)c(OC)c1C1=C(C2C(=O)N(C)C(=O)N2O)C(=O)c2[nH]cc(CCN)c2C1=O</smiles>
$\underset{\mathrm{HCO}_{2} \mathrm{H}-\mathrm{MeOH} \text {, r.t. }}{\stackrel{\mathrm{AgO} \text { (10 equiv) }}{\longrightarrow}}$ $28 \%$ from $\mathrm{H}$

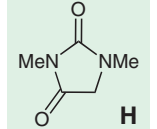<smiles>COc1ccc(CCN(C)C)c(-c2cc(OCC(C)(C)C)c3c(CCNC(=O)O)c[nH]c3c2)c1OC</smiles><smiles>COc1ccc(CCN(C)O[Na])c([18O])c1OC</smiles><smiles>CC(C)(C)OC(=O)CCc1c[nH]c2cc(Br)cc(O)c12</smiles><smiles>CN1C(=O)C2=C(C1=O)C1(Oc3c(O)cc4c(c32)CC[N+]4(C)C)C(=O)N(C)C(=O)N1C</smiles>

Exiguamine A 17 steps, $3.2 \%$

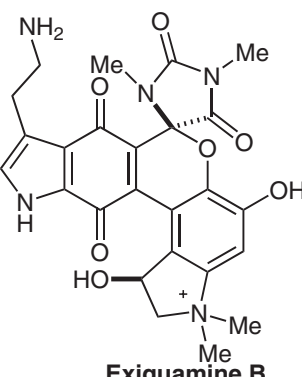

Significance: Exiguamine $A$ is isolated from the marine sponge Neopetrosia exigua and is a potent inhibitor of indoleamine-2,3-dioxygenase, which in turn metabolizes tryptophan. This biomimetic synthesis relies on a cascade sequence involving intramolecular nucleophilic attack of a tertiary amine onto an o-quinone and tautomerization followed by an oxa- $6 \pi$-electrocyclization $(\mathbf{I} \rightarrow$ exiguamine A).
Comment: The phenol resulting from benzyl deprotection of $\mathbf{F}$ was subjected to salcomine oxidation which gave a 2.5:1 mixture of the regioisomeric $o$ - and $p$-quinones, respectively $(\mathbf{F} \rightarrow \mathbf{G})$. Upon treatment with 10 equivalents of $\mathrm{AgO}$, I afforded exiguamine $A$, but with 20 equivalents of AgO exiguamine $B$ was the main product. Treatment of exiguamine $\mathrm{A}$ with excess of $\mathrm{AgO}$ failed to give exiguamine $\mathrm{B}$. 